Article

\title{
Drones and Eucharist
}

\author{
Jason M. Smith \\ Liberal Studies, Tougaloo College, Tougaloo, MS 39174, USA; jason.m.smith521@gmail.com
}

Received: 31 May 2019; Accepted: 26 June 2019; Published: 28 June 2019

\begin{abstract}
In the post-9/11 world, the use of drone strikes has become a critical aspect of U.S. Military strategy in the War on Terror. While the ethics of drones have been argued from a theological perspective, this essay argues that a deeper, more theoretical understanding of drones is necessary in order to mount an adequate theological response. The author argues that the particular epistemological foundations by which drone strikes are justified must be given a theological corrective and that the Eucharist is the site for such a correction. This essay ultimately argues that the Eucharist shows the epistemology that undergirds the use of drones to be severely lacking and that under the judgment of the Eucharist the use of such technology is incompatible with the identity of the Church.
\end{abstract}

Keywords: drones; Eucharist; theology; ontology; apophaticism

\section{Introduction}

On 7 September 2013 an unaccompanied red pickup truck rumbled along a gravel path in the district of Watapur, taxiing a group of passengers to a nearby village. Watapur is a treacherous area to traverse so the drivers in this region have developed something of a buddy system. The truck in question was expected to arrive at its destination around nightfall. It contained a dozen or so members of a family from the area, as well as a lone female passenger hitching a ride through the boggy road ahead. Among the members of the family on board were women and children, one as young as eighteen months old. They would never reach their destination.

At around 5:30 PM they were attacked by what the locals call the ghanghai. They never got a good look at it. It killed several of the right side passengers first, then returned for those trying to flee on foot, then came back one final time and killed any that might have remained hiding in the truck. Most of the trucks passengers were found dismembered or disemboweled when help arrived. A four-year old girl was the sole survivor of the attack, and she was left horrifically mutilated. She was missing her nose, her bottom lip, and her faced was bloodied to the point that her uncle, who was the first to arrive at the scene of the attack, did not recognize her until she spoke to him. "Where is my Father? Where is my Mother?" she asked him.

The ghanghai is a creature with which the denizens of Watapur and surrounding provinces are quite familiar. They have adapted to its intrusion into their country. Locals are known to scatter when they hear the telltale buzzing sound that foretells its approach in order to limit the number of people it can kill. They hear the sound of its approach several times a day. The ghanghai is not, however, a creature, strictly speaking. It is a creation.

"Ghanghai" is the local word for "drone" (Jeong 2018).

\section{Theorizing and Theologizing the Drone}

Why must theologians speak of drones? This will be the central question to which this essay hopes to give an answer. There are, however, several ways to ask this question, each with its own specific emphases. We could ask, "why must theologians speak of drones?" This is to make the question out to be an entirely ethical one that theologians, perhaps because of their metaphysical commitments or 
social locations, have neglected to ask. Those who see the wisdom in asking the question in this way would want to say that the ethical catastrophe of drone warfare must awaken the theologian from their political and, therefore, dogmatic slumber. With the Obama administration's striking admission in 2015 that drone strikes in Pakistan, Yemen, Somalia, and Afghanistan had killed somewhere between 64 and 116 civilians (though many human rights organizations contend the real number is much higher) and the Trump administration's recent refusal to report the number of civilian casualties caused by drone strikes, the ethical questions that press themselves upon the global Church need little assistance in making themselves known (Savage and Shane 2016; Savage 2019).

Another way to ask the central question is, "why must theologians speak of drones?" Those who would ask the question this way imply that speaking is precisely what we do not need. The answer to be given is not a theoretical but a practical one. In this case, to answer the question at all would be to say why theologians in particular ought to join the movements of protest and political resistance against the use of drones. Talk is cheap, after all. Yet, how shall we believe if we have not heard? These two divergent modes of asking obviously caricature a great many aspects of a complex conversation, but they demonstrate what might be described as two tempting directions to take a conversation about drones amongst theologians. Either direction seems to take the question off of terrain we call "properly" theological. That is to say, if we ask the question of drones in either way we seem to be admitting that theologians have very little to say at all about the matter as theologians. They engage the issue only in their role as ethicists or activists.

My intent in this essay is instead to ask the question in this way: why must theologians speak of drones? In other words, what is it about theology, and Christian theology in particular, that ought to compel the theologian, as in keeping with their vocation, to speak about drones? The real heart of the matter will be to answer what it is that such a theologian can or ought to say about the particular problems that drones present to Christian orthodoxy. That means that very little of what I am about to say will have to do directly with ethics. Much of what I will have to say has to do with questions limited to the realm of ontology or metaphysics with an eye towards an ethical correlate of that theory. I imagine this essay as attempting to stand in the tradition of thinkers like Donald MacKinnon who afforded to metaphysical discourse an inevitable ethical correlate since both were concerned with saying what was actually the case (Mackinnon 1982). Thus, to write a 'theology of the drone' is decidedly not to say only what the Christian ought to do or to say only what the Christian ought to believe. As obscure as it may sound, drones require a theological response rooted in matters of ontology and theory precisely because they resist ontological and theoretical categorization. The drone, after all, is a soldier without a body.

The methodological quibble over the true nature of the question at hand is not a new technique by any means in theology. The unique aspect of my argument will be that I take it to be impossible to speak about drones as a theologian, to give a theological response to the problem of drones, without speaking of the Eucharist. Indeed, the central claim of this essay will be that a theological response to the drone must see the drone as nothing less than an "anti-sacrament" so the only source from which to draw a theological corrective must be the sacrament that makes the truth of the Church in the first place, namely, the Eucharist.

In order to reach this claim I want to examine first contemporary responses to the problem of drones, focusing in particular on the recent genealogical account of drones from French theorist Grégoire Chamayou. His work shows, I think, that an idolatrous vision of the human being lies at the heart of what I will call "drone reasoning" or the "drone episteme," i.e., the epistemic frame that allows for the justification of the use of drones in war. Second, I shall turn to a theological genealogy to try and ascertain what a theological response to the problems of drones might look like. For that, I turn to the recent and characteristically ambitious political theology of John Milbank. Thus, I will argue that, seen through a Milbankian framework, a theological response to drones is all the more essential since drones are shown to be the secular weapon par excellence. A theological response to drones is thus an ontological and an ethical response or, more accurately, an ethical response because 
it is an ontological response. Drones, to put it again in Milbank's terms, must be read on theology's terms and not vice versa.

Thus, in my final section I shall turn to the work of this theological account of drones from a Eucharistic perspective. In this theological account, drone reasoning no longer reads the human subject but rather drone reasoning is read by the Eucharist, a rite that displaces that which is knowable about the human person through their encounter and incorporation into mystery. Drones are thereby shown to be an anti-sacrament, the embodiment of communal life that is fundamentally alienation rather than incorporation, ignorance rather than knowledge, absence rather than presence. Thus, that community which is thrown into being by the Eucharist, the Church, is shown always already to be an anti-drone community.

So I begin with the elemental question: what is a drone? There are technical answers to this question, obviously. According to the U.S. Army, a drone is "a land, sea, or air vehicle that is remotely or automatically controlled" (U.S. Department of Defense 2011, p. 109). Yet, any attempt to answer this question more fully— to "theorize" the drone, rather than merely define its use-will inevitably run aground upon negativity and absence. The drone is a weapon without a body. The drone is a gaze without a physical eye. The drone is a soldier that cannot be sacrificed. Grégoire Chamayou charts this series of absences in his Theory of the Drone by giving an account of the changes that the use of drones have loosed upon the world, particularly as it pertains to the way in which traditional norms of warfare have been changed by the emergence of this new technology. For our purposes, however, I want to focus on the theoretical or epistemological changes that the justification for such technology relies upon, as chronicled within Chamayou's genealogy.

According to Chamayou, in striving to emulate the traditional theological dictum that "omniscience implies omnipotence," drones attempt to fulfill a series of strategic principles (Chamayou 2014, p. 37). They are as follows:

1. The principle of persistent surveillance or permanent watch.

2. The principle of a totalization of perspectives or a synoptic viewing.

3. The principle of creating an archive or film of everyone's life.

4. The principle of data fusion.

5. The principle of the schematization of forms of life.

6. The principle of the detection of anomalies and preemptive anticipation (Chamayou 2014, pp. 38-42).

Within these principles, I want to argue that there is present to us a particular sort of epistemology - a series of presumed notions about how knowledge is gained, what we can and cannot know about human persons, and what such knowledge allows us to conclude as certain or established. The use of drones, so I think Chamayou is trying to argue, is only justifiable so long as this presumed epistemic frame holds, so long as archiving forms of life and studying their patterns can lead to successful preemption of certain actions. Allow me to analyze each principle in further detail.

The first two principles show that drones aim to establish a permanent watch on a given target or network and to couple that watch with synoptic viewing. To do so, drones must overcome what is called the "tyranny of distance" (Scahill and the Staff of the Intercept 2017). The tyranny of distance in this case is the forced series of "blinks" in the drone's gaze on its targets caused by the distance drones and other aircraft must traverse in order to reach their mark's location and keep the surveillance feed uninterrupted. In this sense, then, drone reasoning is both literally and theoretically a refusal of distance and an embrace of closure. The subsequent principles of drone reasoning are a consequent to the first two: in overcoming the tyranny of distance one can create an archive of everyone's life, fuse the various sorts of data involved in that archival construction together (video surveillance, cell phone intercepts, etc.), and then construct a schematization of forms of life within a given social network of persons. The permanent gaze of the drone ought to allow one to map out an individual's movement in and out of various social groups so as to fulfill the final principle - to identify emergent threats via 
the identification of deviations from normal forms of life and take preemptive action. In the case of "signature strikes," i.e., drone strikes based on nothing more than a "signature" of deviant behavior, this sort of preemptive action can be undertaken without even having to identify the persons targeted.

It is not difficult to predict Chamayou's critique of this epistemology. The typical rules of drone warfare operate based upon an epistemic overreach that leads directly to dire political consequences. As Chamayou puts it, "[T]he whole problem—at once epistemological and political—lies in [the] claimed ability to convert a series of probable indices into a legitimate target" (Chamayou 2014, p. 49). The overreach, in other words, lies in the epistemic leap from an ambiguous pattern deviation to a matter of actionable certainty. I would argue that such a leap is only possible because drones offer us an imagined world in which people can be known as threats simply by overcoming the tyranny of distance-a world in which terrorists are 'texts,' if you will, which if read completely, or perhaps just sufficiently, will fully reveal their true nature. The distance that prevents this reading is the only barrier to the mission objectives of "Find, Fix, and Finish" (Scahill and the Staff of the Intercept 2017). Drones find their targets through a regime of permanent watch, fix them as targets through pattern of life analysis, and finish them with supposed precision. But, as Chamayou so delicately puts it, "There is a crucial difference between hitting the target and hitting only the target" (Chamayou 2014, p. 141).

Chamayou's ultimate conclusion is that the introduction of the technology of drones portends a concomitant shift in the underlying martial philosophy of war itself. Military action has now become governed by the logic of "manhunting," a logic immune from the typical ethos that once governed what we might call "traditional" warfare (Chamayou 2012, p. 5). This changes fundamental aspects of warfare- the way that States behave towards one another, the distinction between civilians and combatants, and the political calculus involved in waging war. Chamayou is here worth quoting at length:

What is emerging is the idea of an invasive power based not so much on the rights of conquest as on the rights of pursuit: a right of universal intrusion or encroachment that would authorize charging after the prey wherever it found refuge, thereby trampling underfoot the principal of territorial integrity classically attached to state sovereignty. According to such a concept, the sovereignty of other states becomes a contingent matter. Full enjoyment of that sovereignty is recognized only if those states take imperial tracking to heart- "failed" states cannot, "rogue" states will not—-their territories can legitimately be violated by a hunter-state (Chamayou 2014, p. 53).

Yet, for my purposes, what is more striking is that drones have introduced a new matrix of military jargon - coupled inexorably to the logic of manhunting that Chamayou describes- that seems to steer certain situations that ought to be innocuous towards disastrous results. Andrew Cockburn's Kill Chain opens with such an incident, wherein twenty-three civilians were killed by an air strike coordinated by drone operators and spurred on by anxiety over the two to five second delay in the relay of images from the drone itself. More than just the delay, however, is the linguistic covering over of human beings that turns men, women, and children into something different. Cockburn writes, 'The crews spoke a language almost incomprehensible to outsiders, so laden with acronyms that plain English was often supplanted. But that night's conversations show that the military jargon, like the two-second video delay, imposed another layer between them and the reality on the ground. Any MAM (military-aged male) became by definition an enemy fighter, irrespective of age, and therefore a legitimate target" (Cockburn 2015, p. 8). Ultimately, what becomes clear is that using drones insulates one from the typical manner of experiencing human beings, both physically and linguistically. The arresting nature of a genuine human encounter, that which causes one to recognize the limits of one's knowledge in encountering an Other, is displaced in and through the visual and linguistic experience of drone operation.

It is that linguistic displacement that Solmaz Sharif attends to masterfully in her recent collection of poems, Look. Sharif interpolates terminology from the Department of Defense's Dictionary of Military and 
Associated Terms into her poetry so as to throw light upon the ways in which the language of the D.O.D. is at odds with the poetic way in which we seek to understand our own being as humans. The contrast between the spartan mode of military speech and the intimate nature of Sharif's re-presentation of embodied particularity reveals the displacement of human mystery that is at the heart of the drone's gaze. "It matters what you call a thing," Sharif begins, and in this beginning is perhaps the whole of what one needs to criticize in the U.S. Drone Program (Sharif 2016, p. 3). Yet, there are several moments of poesis that seem to make present for the reader the precise linguistic displacement of which I am speaking. Some are quite direct, (note: the words in ALL CAPS are drawn from the DOD Dictionary): "Daily I sit with the language they've made of our language to NEUTRALIZE the CAPABILITY of LOW DOLLAR VALUE ITEMS like you" (Sharif 2016, p. 64). Some instances utilize religious allusions: "Whereas ye know not what shall be on the morrow. For what is your life? It is even a THERMAL SHADOW, it appears so little, and then vanishes from the screen" (Sharif 2016, p. 4). Sharif shows, in sum, that the ultimate effect of this sort of linguistic innovation is, in fact, a calculus removed from humaneness: "In EXECUTION PLANNING, they weighed/the losses, the SUSTAINABILITY/and budgeted/for X number//they budgeted for the phone call/to your mother and weighed that/against the amount saved in rations/and your taste for cigarettes" (Sharif 2016, pp. 64-5).

Ultimately, what Chamayou, Cockburn, and Sharif reveal is that the thinkability or imaginability of the use of drones is not merely a byproduct of technological innovation. It is not merely, in other words, that we have built the bombs and therefore are going to drop them. The problem of drones runs deeper. Drones are the end result of a particular epistemology or, perhaps better, a desire for a certain epistemological state of affairs that makes thinkable a certain relationship between war and the state, combatant and civilian. It is a way of knowing that sees human life as subject to surveillance, classification, and pattern of life analysis. It is a way of knowing that relies upon a particular linguistic distortion of human life and finite reality-a displacement, through language, of the natural yet excessive mystery at the heart of being itself. Hence, theology cannot respond to the ethical quandary of drones with an ethical recommendation for new modes of action-though this will certainly be a part of any theological critique-but instead must respond in kind. The way of knowing at the root of the use of drones must be read theologically and a theological corrective as a form of counter-ontology must be offered. It is to the beginning of that counter that I now turn.

\section{The Drone as Secular Weapon}

When faced with this linguistic displacement of human mystery, I want to claim that theologians can do more than simply suggest a new vocabulary to the D.O.D. Instead, I want to claim that the particular gift theology can give in this moment is not just an ethical prescription but rather a theological account which shows the episteme at the root of drone reasoning to be incompatible with Christian orthodoxy. This will mean, ultimately, that drone reasoning is not merely mistaken but idolatrous and thus requires a theological corrective in order to begin the work of making thinkable an ethical alternative.

I would like to do this through a recent work of political ontology from John Milbank. In Beyond Secular Order, Milbank has attempted to trace the roots of how problematic ontological thinking, particular the ontological moves of modernity, becomes a problematic frame for political action (Milbank 2013). His argument rests on the notion that "ideas about being coincide with ideas about human action" (Milbank 2013, p. 3). Now, that is clearly a contestable proposition, but I want to assume it for the moment to show not only the usefulness of some aspects of Milbank's genealogy but also how that genealogy helps us to analyze the particular phenomenon of drone warfare. For if we assume that ideas about being really do coincide with ideas about human action then a genealogy of modern ontology ought to flow directly into a genealogy of modern political realities. This is the root of Milbank's fascinating decision to call a portion of his work a "political ontology" (Milbank 2013, p. 114). In short, political constructions are contingent realities whose origins can be traced genealogically, but for Milbank, if I have read him correctly, the theologian must trace these genealogies 
not merely through the vicissitudes of cultural or material realities, but ontological ones as well. So to peer into the history of the philosophy of being is also to peer into the bedrock of those systems of political legitimacy that have come to characterize modernity as a whole.

Thus, Milbank's genealogy begins with what he calls four pillars characteristic of modern ontology. They are: (1) univocity over analogy of being, (2) knowledge by representation instead of identity, (3) the priority of possibility over the mysterious depths of actuality, and (4) divine causality as concurrence within the same causal plane rather than influence through a series of hierarchical causal chains (Milbank 2013, p. 3). Here Milbank is singing a tune quite familiar to those who have followed the work of he and his cohorts associated with the Radical Orthodoxy movement. Milbank's broad claim here is still much the same as that which he advanced in Theology and Social Theory some decades ago, namely, that being itself-our idea of it and, therefore, the way in which we choose to act within it-was emptied of a mystery that was proper to it in the transition from the Middle Ages to the Secular Age (Milbank 1997). In other words, being was once held to be naturally mysterious, not as the secret bearer of some hidden divine presence. This natural mystery proper to being and, consequently, to beings, is drained away in the transition from pre-modern ontology into an ontology governed by the four pillars that Milbank is describing. For my purposes, I want to claim that when we take the four pillars together a compelling thesis comes into view: the drone can be classified as a fundamentally secular weapon because without the modern ontological turns I am about to describe the drone's primary foundation for the justification of its use would be rendered untenable.

As to the first pillar, one of the characteristic arguments of radical orthodoxy comes into view. First, the characteristic argument of much of what is known as radical orthodoxy berates John Duns Scotus' thesis of the "univocity of being." What this phrase entails is a dispute between Aquinas and Scotus on what the proper mode of predication was for God and for creatures. Now, before I recount Milbank's argument here I should note that his reading of both Scotus and Aquinas have come under heavy criticism, to the point that his readings of either figure is nearly untenable (Horan 2014; DeHart 2012). What use then can I have for his arguments? While I take Milbank's historical assertions to stand on highly questionable grounds I do believe his use of these two figures as paradigms of sorts for certain streams of thought within the broader current of modernity does stand. Thus, in the coming paragraphs perhaps it is best to think always of these two figures as "Milbank's Scotus" and "Milbank's Aquinas" respectively.

Milbank sees in Scotus' theory of univocity in religious language a disastrous misstep. Put in a less abstract way, Scotus thought that what we attribute to God could be attributed to creatures in the same voice, i.e., univocally (Scotus Ordinatio, 18/19). In other words, when we say that God is good and that this essay is good, we are using a notion of goodness that is common to both of them, though the latter possesses goodness to a far lesser degree than the former. Yet, critically, there is no inherent difference between what we mean by good in each instance. We are still speaking in the same voice about God being good and the essay being good. This is, so Milbank argues, a marked shift from the mode of predication that had been prevalent amongst theologians prior to Scotus. Before this inflection point in theological language, analogy had been the mode of predication that was seen as primary (Milbank 2013, pp. 50-57). Thus, when we say that God exists and that Liverpool Football Club exists, we are not saying that these two share the same sort of existence. We are speaking analogously. Under Scotus' paradigm, however, God and Liverpool Football Club would share the same sort of existence, albeit at different levels of intensity. To dramatically simplify the dispute, Aquinas sought to protect the distance between God and creatures by ensuring that theological language, while able to speak truthfully, is always out of its depth so to speak. Scotus sought to protect the legitimacy of theological claims by asserting that whatever is good about our created life must be held by God in spades.

This might seem like an inquiry confined solely to theoretical concerns but the implication of this thesis, in Milbank's estimation, is vast and far-reaching. The consequence of this shift towards univocity is that existence now must be predicated in precisely the same, univocal manner to God and 
creatures. This means, ultimately, that being is a neutral thing that both God and creatures possess in the same way. So any knowledge within this horizon of being will be fundamentally determined by this sameness and accessibility.

Secondly, knowledge by representation instead of identity refers, for Milbank, to the epistemological shift that came to see true knowledge as an accurate "copy" within the mind. This was in contradistinction to the traditional sense of knowledge that held to know something was to be united to it via one's intellect. For the first time, so Milbank's argument goes, an "object" emerged rather than a synthesis of form and matter. Thirdly, our idea of reality came to be dominated by what Milbank calls the priority of the possible. The big idea here is that in modernity we view reality as determined most fundamentally by a prior possibility or by a matrix of acceptable possibilities rather than by what is actually in front of us. So rather than reality disclosing a partial image of the divine glory, we are forever haunted in our knowledge of the world by the idea that it might have been otherwise. Perhaps this point is best understood if one notes the difference between the following phrases "reality as gift" and "reality as a given." Finally, and perhaps most critically, this view of reality changes the way in which God can be said to act within reality. The theological notion of concurrence is not necessarily invented during this period but comes to take center stage in explanations about how it is that God can be said to act within the causal order without overriding the freedom and dignity of creatures. There are many variations on this theme, but what Milbank wishes to hammer home is that the prior three pillars are theological moves that preeminently culminate in this move, which would see God as one causal actor among others within the same neutral field of being. Again, the view of reality here is what is critical. Beings, in order to be free, must be free from divine causality. Freedom of God and freedom of creatures becomes an either/or rather than a both/and-either God is acting freely or a creature is acting freely, but to say that both occur at the same time is a difficult proposition to defend from the univocal perspective.

Now, what I've just recounted surely invites critical responses from the perspectives of historical theology and contemporary systematic theology. As I said above, critiques of Milbank's oeuvre are certainly not few and far between. Adjudicating the accuracy of his readings of John Duns Scotus as the great boogeyman or of Thomas Aquinas as ur-theologian of radical orthodoxy is beyond the scope of my argument. What I do want to claim is that his genealogical sequence bears surprising fruit when put in dialogue with the problem of drones. Milbank's work is useful in bringing the following to light: whatever we are to make of his charge that the entirety of the secular order is grounded in a draining of mystery from reality, it is surely the case that drone warfare can only operate off of an anthropology that is based in an ontology like the one Milbank is describing. Thus, I think it is telling that Milbank's first step after leveling his critical faculties against modern ontology is to launch into a constructive effort aimed at rebuilding an adequate account of the human being. In short, the critical connection that Milbank makes is between the way we imagine reality and the way in which we then imagine what it ought to be like for human beings to belong together within said reality. If that reality is drained of a mystery that was once considered proper to it, then the human being is also now deprived of a particular type of dignity. My reading of Milbank thus brings forth the claim that it is only this loss of mystery that justifies a regime of permanent watch as a viable solution to violence. Whatever systems of thought drones might be grounded within-capitalism, neoliberalism, etc.-it is theology that reveals that the roots of the drone episteme I have been describing are not merely ontological but theological. The linguistic displacement of the natural, yet supernatural mystery inherent to an adequate ontology and a dignified anthropology requires not only a theoretical corrective, but a theological response.

\section{Drones and the Judgment of the Eucharist}

If theology is essential to the task of naming the problem of drones then theology ought also to be indispensable for the problem's solution. What we seemed faced with is the need for an orienting point that could both refute the ontological problems of drone reasoning without dealing in a similar 
refusal of mediation and mystery. It is my contention that the appropriate site of a theological response to the problems of drones, therefore, is the Eucharist, wherein we encounter the authentic presence of God and of ourselves in an embodied, mysterious act. If drones rely on a linguistic displacement of this sort of authentic presence, then it will be our focus to discover how it is that the Eucharist refuses such a displacement and does so precisely in and within language. The Eucharist will thus be shown to be a form of language that incorporates us into an authentic sort of human belonging. The Eucharist, in other words, fundamentally shapes the identity-forming waters that we swim in, so to speak, by calling forth particular forms of human belonging. Yet, crucially, what I want to claim is that the form of belonging that the Eucharist calls forth is made possible by a fundamentally mysterious form of belonging into which the Eucharist incorporates us-that is, the mystery of the Trinitarian life of the Godhead. Thus, the Eucharist does displace our identities in language, but it places us into the mystery of the Trinity's perichoresis, wherein our identity is only to be found in the identities of those to whom we belong as members of one Body. While Chamayou sought to claim, rightly of course, that the drone is a sort of "anti-kamikaze," I want to put a theological spin on this by arguing that the drone is a sort of "anti-sacrament." Where the Eucharist is an instituting sign of the "presence of absence," the drone is a vacuous sign of the "absence of presence."

To make this case, I want to turn to the work of Louis-Marie Chauvet, whose seminal work on the Eucharist has most closely investigated the relationship between the Eucharist and absence. Chauvet is primarily concerned with understanding the Eucharist according to two fundamental categories: gift and symbol. More importantly, the understanding gained by investigating these two categories ultimately reveals not just a clearer picture of the Eucharist, but a refined picture of what it means to be human. It is by traveling the path through gift and symbol—by submitting to them, as Chauvet will say-that we discover a proper understanding of the Eucharist and a proper sense of human identity as gifted therein.

For Chauvet, the Eucharist occupies an odd place within the economy of grace. The rite is located, so to speak, right at the heart of a dialectic between being "instituted" and "instituting." On the one hand, the Eucharist was given to the Church. Hence, the traditional claim that the Eucharist, along with the other seven sacraments, were in some way "instituted" by Christ. The Eucharist, in, "escapes" the Church - the Church does not have full control over the rite because it did not create it (Chauvet 1995, p. 377). Yet, on the other hand, the instituted nature of the rite is the foundation of the "instituting" nature of the Eucharist. Tellingly, Chauvet can only describe this instituting nature of the rite by referring to language. The Eucharist institutes us as human subjects into new identities as Christian subjects. The Eucharist brings us into what Chauvet calls the "language-game of faith." (Chauvet 1995, p. 378).

At the heart of this rite, however, is the more controversial question of transubstantiation. For Chauvet a great deal turns on the true nature of Eucharistic change: how we conceptualize this encounter with the grace of God in the rite will have tremendous effect on what kind of identity is instituted by the rite itself. Critically, for Chauvet the identity into which we are instituted by the Eucharist- the language-game within which we are submersed in and through our faith-is the mystery of the "presence of absence" (Chauvet 1995, p. 63). Avoiding the traditional axioms of Scholastic theology, which Chauvet thinks should be dismissed as ontotheological, Chauvet argues instead that the Eucharistic presence is not a graspable, objective presence. It is rather a presence the nature of which is constituted by absence. This is most seminally revealed in the fact that the bread only has its true essence in being broken. It is the fissure opened up in the bread-not simply the bread as a whole - that most truly signifies the presence of the One whose body was broken for us.

The Eucharist for Chauvet thus becomes a sort of sacred pedagogy—a rite by which we learn to come back to the real truth of the subject by consenting to the presence of absence (Chauvet 1995). For Chauvet, then, transubstantiation is not the indwelling of the presence of Christ in the bread that is whole. Rather, the Eucharistic presence is now something that escapes us, it is the presence of God as absent in the breach of the bread as broken. Chauvet walks a decidedly tight line, but it is 
an essential one: God communicates God's very self to us in the Eucharist, but this communication is the self-communication of a God who chooses to become present as the Absent One. Chauvet's great innovation here is insisting that presence and absence are not mutually exclusive realities in the Eucharist. The Eucharistic presence is the presence of the absence of God, but it is also true that in the absence of the broken bread God is indeed truly and fully present.

I said above that Chauvet's theology can go from the Eucharist to theological anthropology or vice versa. Thus, one could say that we learn to consent first to the presence of the absence of God so that we can learn to consent to the presence of absence in ourselves. Chauvet sees in the Eucharist almost a fitting anticipation of a great deal of postmodern theory. He appropriates the insights of those like Heidegger and Lacan who assert that true human subjectivity is not defined by an objective or static essence but by processes of becoming and mediation (Chauvet 1995). We, ourselves, are constituted by mediation because we come to be subjects in and through symbol-those communicative signs, either verbal or otherwise, by which we encounter and confront other people. Language itself forms a sort of gift-exchange wherein we gift to other people that recognition that forms their subjectivity and receive back in return a similar recognition for ourselves. Most importantly, and here Chauvet is absolutely adamant, this process is one that is continual and unending (Chauvet 1995). In other words, the Eucharist does not give to us the sort of epistemic assurance that the principles of drone reasoning outlined above purport to do. The Eucharist seems to be entirely at odds with such an episteme. For in the Eucharist we are confronted with our own immersion in symbol, and yet this immersion is not a barrier to the truth of our subjectivity but is itself the basis for our identity in the first place. We are symbolic beings and we show forth the same sort of mysterious presence as does the God whom we encounter in the broken bread. We are, in short, confronted, even within our own self-understanding, with the presence of absence. It is only in learning to consent to this absence, in learning to embrace rather than eschew the mediation of symbol, that we come to find our true selves.

Critically, however, the Eucharist is not just a pedagogy. Perhaps for our purposes it might be enough to say that the Eucharist teaches us a different vision of the nature of personhood as a counter to the epistemic frame that undergirds the use of drones. Yet, if as Milbank asserted "thoughts about being coincide with thoughts about human action" then it does, in fact, matter what sort of account we give of the presence of absence in the Eucharist. For Chauvet, it is not merely that the Eucharist challenges our ways of thinking about God and human beings, encountering sacramental grace in the Eucharist is an incorporation into the Trinitarian relations (Chauvet 1995, p. 531). This means, I would argue, that the "ontological scandal" of the Eucharist, so to speak, is an incorporation into mystery. In the wake of the Eucharist, there is then a necessary apophaticism to our "ideas about being"-we are bound by the Eucharistic presence to speak now of ourselves as having our identity in relations that fundamentally escape our epistemological capacity. I have my differences with Chauvet's account of the nature of such a mystery-he favors a more Reformed vision of the deus absconditus out of fear of ontotheology associated with more traditional apophaticism—but the overall point I am trying to make is still in line with much of his work. The Eucharistic presence is not just a pedagogy for consenting to the presence of absence, it is rather an incorporation into that very presence of absence-i.e., into the life of the Godhead that is fundamentally mysterious.

Ultimately, an adequate theological counter to drones must be rooted in a sort of counter-epistemology to the epistemic frame that helps to justify the use of drones. This counter-epistemology will be rooted in ideas about being and personhood that are inculcated in us, as all concepts that make up our deep background of the world are, through language. The Eucharist is, I am arguing, just this sort of epistemic frame-a counter-ontology to the ideas about being inherent in the drone episteme that see human beings as texts to be read and, if the patterns therein are found to be suspicious, erased. It is thus a particular "language-game" as Chauvet says that places the human person as first and foremost having their identity in symbolic mediation and having its final telos in the mystery of the divine perichoresis of the Trinitarian relations. 


\section{Conclusions}

Ultimately, what I think this small work of bricolage leads to is something like the following claim: the Eucharist is the site in which a Christian vision of the ontological and political meaning of mystery is encountered. In receiving the sacrament, we find ourselves doing two things: first, submitting to the order of signs as the very site of divine revelation. Second, and more importantly, we find ourselves gifted with a new way of speaking of how we belong to one another, precisely in and through submitting to the order of signs. Our typical way of speaking about how we belong to one another is displaced in favor of a fundamentally new mode of belonging: sharing in a common mystery that is both radically transcendent and as mundane as our daily bread. But, there is ever the recognition that these new manners of speaking are not final, but rather, they point beyond themselves to a manner of belonging that shall one day become final. This means that if we try to build a Christian political theology from the Eucharist (or a foreign policy, for that matter!) it will have very little to say with finality. It will look more like what Derrida famously called the "democracy to come" (Derrida 2005, p. 8). What such a political theology can do with great emphasis, however, is to note the way that the Eucharist stands in judgment over all other forms of human belonging, precisely in its refusal to speak with the finality that so many other forms of political discourse ground themselves upon. It would look like a political theology of apophasis or a politics grounded in askesis.

Drones, therefore, when placed under the judgment of the Eucharist, are seen to be something like an anti-sacrament: a sign that signifies a poverty of true negativity, a symbol of the refusal of symbol. It is no wonder, then, that such a "sign" can form no community and can bring no justice. For drones rely on a covering over of that fundamental mystery at the heart of human belonging in favor of an epistemology that sees in "patterns of life" nothing further than nodes of a mappable social network. Thus, the drone gives rise to the peculiar state of military affairs in which our world finds itself-constantly at war with no one in particular.

An epistemology that refuses to consent to the presence of absence-whether in ontology, in subjectivity, or in the Eucharistic community of the Risen One who is "not here" - cannot adequately ground a community striving for the common good. And it is, I think, chiefly the ontological and subsequent political scandal of the Eucharist that brings this to light. The Church, therefore, is always already an anti-drone community. For the Church dares to give primacy to a particular, located flesh and to eschew a gaze other than that gaze which looks out in love and forgiveness. Indeed, it must do this, since the root of the Church's entire idea about its being comes from a rite in which our ready to hand ideas about subjectivity are displaced by locating the truth of all subjectivity in Trinitarian mystery. Such a community can only see reality as a gift to be received and, consequently, can only see those whom it comes into contact with as unsurveillable-in other words, as their neighbor.

Obviously, the Church does not always behave in this way. The form of belonging that the Eucharist calls forth-that incorporation into the Trinitarian mystery that constitutes our identities, both individually and communally, as mysterious-is often neglected or even contradicted by the lives of the faithful. I am also not arguing that simply partaking of the Eucharist will be enough to make Christian communities around the world into the sorts of communities where that type of being-with is the identity we seek to live out of each day. In this sense, as I have written elsewhere, one could say that every Eucharist fails. Each meeting at the Lord's Table promises the presence of a new community and with each meeting it becomes quite obvious that such a community will not have any lasting presence on this side of the veil of tears. What I am arguing, however, is that the vision of the Body of Christ- the momentary transfiguration of the crooked timbre of human community into the congregation of the glassy sea-is the proverbial north star of the Christian imaginary. Drones, I have argued, are simply not compatible with this theological vision of dignified human life.

Funding: This research received no external funding.

Acknowledgments: The author wishes to thank the Critical Theories seminar group of the North American Academy of Liturgy for their comments on an earlier draft of this article. 
Conflicts of Interest: The author declares no conflict of interest.

\section{References}

Chamayou, Grégoire. 2012. Manhunts: A Philosophical History. Translated by Steve Randall. Princeton: Princeton University Press.

Chamayou, Grégoire. 2014. A Theory of the Drone. Translated by Janet Lloyd. New York: The New Press.

Chauvet, Louis-Marie. 1995. Symbol and Sacrament: A Sacramental Reinterpretation of Christian Existence. Translated by Patrick Madigan S. J., and Madeleine Beaumont. Collegeville: Liturgical Press.

Cockburn, Andrew. 2015. Kill Chain: The Rise of High-Tech Assassins. New York: Henry Holt and Company.

DeHart, Paul. 2012. Aquinas and Radical Orthodoxy: A Critical Inquiry. New York: Routledge.

Derrida, Jacques. 2005. Rogues: Two Essays on Reason. Translated by Pascale-Anne Brault, and Michael Naas. Stanford: Stanford University Press.

Horan, Daniel P. 2014. Postmodernity and Univocity: A Critical Account of Radical Orthodoxy and Jon Duns Scotus. Minneapolis: Fortress Press.

Jeong, May. 2018. Losing Sight. The Intercept, January 27.

Mackinnon, Donald. 1982. Prolegomena to Christology. The Journal of Theological Studies 33: 146-60. [CrossRef]

Milbank, John. 1997. Theology and Social Theory: Beyond Secular Reason. London: Blackwell.

Milbank, John. 2013. Beyond Secular Order: The Representation of Being and the Representation of People. London: Wiley Blackwell.

Savage, Charlie. 2019. Trump Revokes Obama-Era Rule on Disclosing Civilian Casualities Outside of War Zones. The New York Times, March 6.

Savage, Charlie, and Scott Shane. 2016. U.S. Reveals Death Toll from Strikes Outside War Zones. The New York Times, July 1.

Scahill, Jeremy, and the Staff of the Intercept. 2017. The Assassination Complex: Inside the Government's Secret Drone Program. New York: Simon \& Schuster.

Sharif, Solmaz. 2016. Look. Minneapolis: Graywolf Press.

U.S. Department of Defense. 2011. Dictionary of Military and Associated Terms. Joint Publication 1-02; Washington: The Joint Staff.

(C) 2019 by the author. Licensee MDPI, Basel, Switzerland. This article is an open access article distributed under the terms and conditions of the Creative Commons Attribution (CC BY) license (http://creativecommons.org/licenses/by/4.0/). 